\title{
Date Fruit and Seed in Nutricosmetics
}

\author{
Khlood Lafi Alharbi ${ }^{1,+}$, Jegadeesh Raman ${ }^{2,+}$ and Hyun-Jae Shin ${ }^{1,2, *(D)}$ \\ 1 Department of Beauty and Cosmetology, Graduate School of Industrial Technology Startup, \\ Chosun University, 309 Pilmun-daero, Dong-gu, Gwangju 61452, Korea; khuloodhalharbi@hotmail.com \\ 2 Department of Biochemical and Polymer Engineering, Chosun University, 309 Pilmun-daero, Dong-gu, \\ Gwangju 61452, Korea; ramanjegadeesh@gmail.com \\ * Correspondence: shinhj@chosun.ac.kr \\ + Contributed equally.
}

Citation: Alharbi, K.L.; Raman, J.; Shin, H.-J. Date Fruit and Seed in

Nutricosmetics. Cosmetics 2021, 8, 59. https://doi.org/10.3390/

cosmetics 8030059

Academic Editor: Christophe Hano

Received: 25 May 2021

Accepted: 12 June 2021

Published: 24 June 2021

Publisher's Note: MDPI stays neutral with regard to jurisdictional claims in published maps and institutional affiliations.

Copyright: (c) 2021 by the authors. Licensee MDPI, Basel, Switzerland. This article is an open access article distributed under the terms and conditions of the Creative Commons Attribution (CC BY) license (https:// creativecommons.org/licenses/by/ $4.0 /)$.
Abstract: Many recent studies in the field of cosmetics have focused on organically sourced substances. Products made from organic materials are safe, high quality, cruelty-free, and more effective than those made from synthetic materials. Many organic compounds are known to be physiologically active in humans and have an extended storage capacity and long-lasting environmental effects. Agro-industrial waste has recently increased substantially, and the disposal of date palm waste, often performed in primitive ways such as burning, is harmful to the environment. Fruit processing industries generate over $10 \%$ of the total date seed waste daily, which could be converted into useful food products. Date fruit and seed are rich in sugar, vitamins, fiber, minerals, and phenolic compounds with antioxidant and anti-inflammatory properties that significantly promote human and animal health. This waste is rich in bioactive compounds and essential oils used in many kinds of food, medicine, and cosmetics. Most active cosmetic ingredients come from natural sources such as fruit, fish, and dairy, and recent research shows that date extract and seed oil help to reduce melanin, eczema, acne, and dry patches, while increasing skin moisture and elasticity. This review details the bioactive compounds and nutraceutical properties of date fruit and seed, and their use as cosmetic ingredients.

Keywords: date palm; natural by-products; date fruit; date seed; nutricosmetic

\section{Introduction}

The palm tree is a basic food source in the Arabian Peninsula and has been recognized as a significant economic crop for the last 7000 years [1]. Globally, 2000 varieties have been cultivated, and $10 \%$ of them have been described according to the fruit characteristics [2]. Saudi Arabia is a major producer of date palm. Exports registered a $27 \%$ rise in the middle of 2019 [3], and the demand and production rate have been increasing rapidly. Date fruits are affordable and rich in fiber and energy and are considered as a staple food along with grains, potatoes, and rice. The developmental stages of dates have internationally adopted Arabic names according to their stages of maturity, such as Hababauk, Kimry, Khalal, Rutab, and Tamar (Table 1). The stage of maturity, yield, physical condition, flavor, texture, and nutritive value is affected by agricultural practices and climatic conditions. Moreover, date seeds, leaves, pollen, fruits, and trunks are used to treat a variety of ailments [4]. The fruit comprises a fleshy pericarp and one seed, which constitutes 10-15\% of its weight [5]. Date seeds can stay dormant for many years and grow when favorable circumstances resume [6]. 
Table 1. Growth stages of Phoenix dactylifera (Medjool) Al-hajjaj and Ayad, 2018 [7].

\begin{tabular}{ccl}
\hline Arabic Name & Stages (Weeks) & \multicolumn{1}{c}{ Fruit Maturity Characters } \\
\hline Hababauk & 1 to 5 & The first stage of development after pollination. \\
\hline Kimry & 6 to 16 & $\begin{array}{l}\text { Fruit is small, green, and the moisture content is } 85 \% . \text { The } \\
\text { weight and the concentration of tannins is high. }\end{array}$ \\
\hline Khalal & 17 to 20 & $\begin{array}{l}\text { Fruit reaches maximum weight, starts to become yellow or red, } \\
\text { and becomes rich in sucrose. }\end{array}$ \\
\hline Rutab & 21 to 24 & $\begin{array}{l}\text { Water content is gradually reduced, and the fruit becomes soft, } \\
\text { sweet, and dark. Sucrose is converted into reduced sugars, and } \\
\text { the protein, ash, and fat content is decreased. }\end{array}$ \\
\hline Tamar & 25 to 27 & Final stage of maturity; the fruit is sweet, dark brown and wavy. \\
\hline
\end{tabular}

The date palm, Phoenix roebelenii, is native to southeastern Asia and grows in tropical and subtropical regions. It is the main crop of the Arabian Peninsula, North Africa, the Middle East, and across Southwest Asia [8]. The total area under date palm cultivation across the world is 1,092,104 ha, with a total production of 9,075,446 $\mathrm{t}$ [9]. The lead producers of date palm are Asia and Africa, with a total production share of $57 \%$ and $42.2 \%$, respectively [9]. The top 10 date-producing countries are illustrated in Figure 1 . Saudi Arabia was the second largest date producer from 2018-2019, with a total production of $1,483,631 \mathrm{t}$ [9]. The wild Indian date palm (P. sylvestris), which is exploited for the sugar in its sap, resembles $P$. dactylifera (Ajwa) and is cultivated commercially. The Ajwa variety is described as "super date" and is considered to be highly nutritional and therapeutic [10]. Dates are an indispensable source of dietary metals and free amino acids, and have been used to treat chronic illnesses and diseases since ancient times [11]. They have also been found to reduce high blood pressure and oxidative stress, and have been used to treat diabetes, cancer, and atherosclerosis, and to stimulate immunity [12]. In addition, they have a higher antioxidant activity than culinary fruits [13] and contain several bioactive compounds, such as coumaric acids, ferulic acid, cinnamic acid, flavonoids, procyanidins, phenolic compounds, and water-soluble vitamins [14]. These compounds can strengthen bones, promote uterine contractions in pregnant women during childbirth, and prevent anemia [15]. Additionally, Ajwa and other date varieties can prevent cancer, cardiac arrest, and neuron damage, and can also increase fertility $[5,16]$.

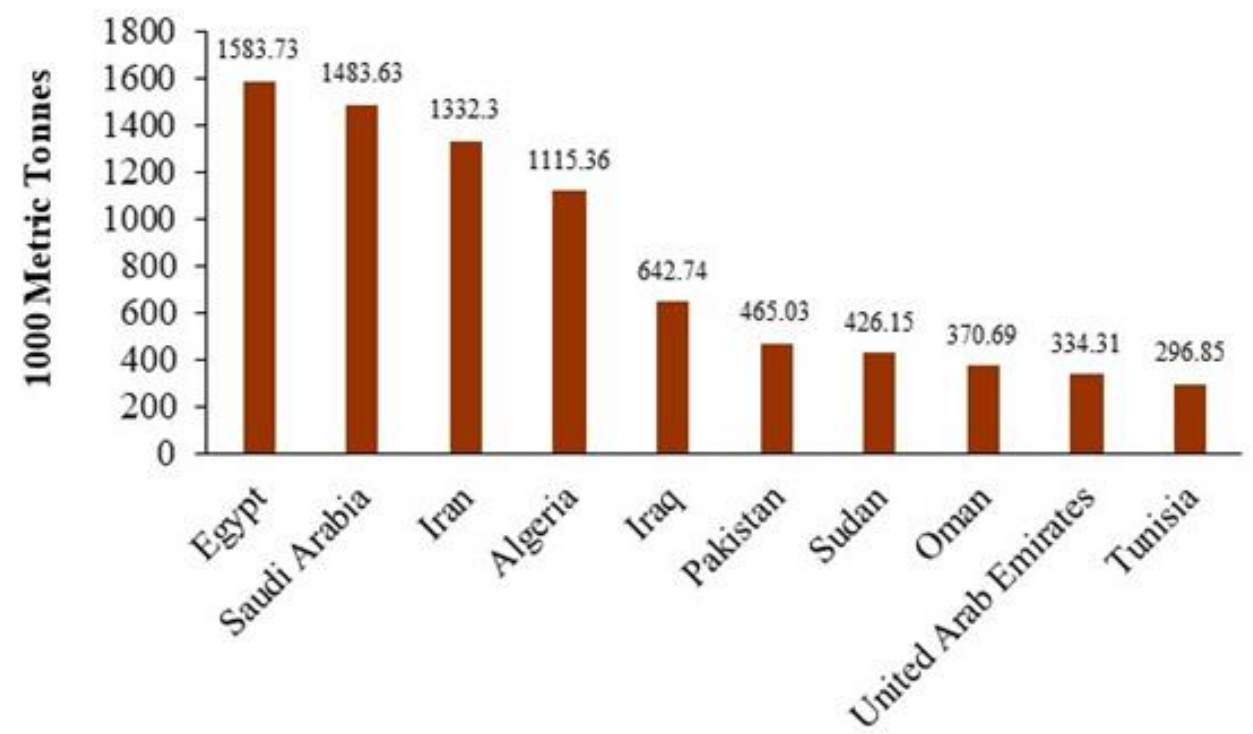

Figure 1. Top 10 date-producing countries (FAOSTAT, 2018 and 2019). 
The cosmetics industry has been one of the fastest growing industries and is flourishing globally. Using the inedible extracts of fruits and vegetables, instead of disposing them by burning, prevents a severe threat to the environment [17]. Date seeds are a rich source of bioactive compounds and are important ingredients within the cosmetics industry, also serving as food additives [18]. A recent study showed the importance of recycling date waste and that date pit powder can be used as a cosmetic product (eyeliner), which does not exert toxic effects on the eye [19]. Extraction of waxes from date palm leaves could be carried out to obtain compounds of potential value from the biomass of this waste. This could provide new possibilities for natural wax production. The demand for natural waxes is steadily increasing due to customers' preferences for green, sustainable, and natural cosmetic products [20]. Date fruits and seeds have been reported to possess antiaging properties and overcome wrinkling of the skin in women. Date waste is believed to contain many essential components that strengthen the hair and skin, prevent early graying of hair, stop wrinkle development, and give the skin a fresh look [21]. This review summarizes the current knowledge on the phytochemical components in date seeds and their use in beauty products.

\section{Sustainability of Date Palm}

Dates contain high levels of sugar and fiber and have high economic value [22]. The worldwide date production, industrialization, and utilization has been continuously increasing over the years, as per the FAO [9]. This has led to a rapid increase in date fruit waste and agro-waste during the period of fruit maturation and harvesting. Storage and conditioning may also increase fruit waste [23]. Moreover, date waste causes serious environmental problems, most notably the emission of gases into the atmosphere, which leads to global warming [24].

\subsection{Date Palm Fruit}

Palm trees have played an essential role in the Gulf region's environment due to its wide use in landscaping. Moreover, cultivated palm tree products are also widely used in the diet in this region. The tree consists of different parts, such as the leaflet, rachis, and fibers. The parts never fall naturally and are removed manually. The large leaves are recycled, and the residues are components of biomass that can produce value-added products. More than 30 million palm trees have been reported in the UAE alone, and each palm tree produces an average of 15 new leaves every year. Each leaf has a dry weight of about $3 \mathrm{~kg}$; therefore, the average production of each palm is about $25-30 \mathrm{~kg}$. The surface fibers and additional waste fruit clusters $(10-15 \mathrm{~kg})$ create a total of $40 \mathrm{~kg}$ of waste/tree, and the annual waste is calculated at 1.2 million tons [25]. The same study also included a rapid thermal gravimetric analysis of date palm ( $P$. dactylifera) leaflet, rachis, and fibers. Each part was decomposed at different temperatures and time. Bio-oil and non-condensable gas were obtained during the pyrolysis process. Among those components, $38.8 \%$ was bio-oil, $10.4 \%$ was reaction water, $37.2 \%$ was bio-coal, and $24.0 \%$ was non-condensable gas. The overall energy conversion efficiency was $87.0 \%$, indicating a high potential for converting date palm waste into energy while eliminating the polluting impact on the environment and the cost associated with the disposal of this waste [26].

\subsection{Date Seed}

The non-edible seed portion is usually discarded after consuming date fruits; they may be scattered and sown in fields. Seed propagation is the easiest and quickest method of propagation and may yield hybrid seedlings. Date fruits consist of the epicarp, a fleshy mesocarp (pulp), and an endocarp consisting of a seed called a kernel or pit [2]. The palm agro-industry and processing industries have generated vast amounts of seed waste and date press cakes. Additionally, a high production rate, improper handling, and lack of scientific knowledge may increase the wastage by more than $30 \%$ of the production values [27]. The agricultural wastes consist of cellulose, hemicelluloses, lignin, and other 
compounds used in many biological processes. Additionally, the agro-waste and industrial waste materials can be used to prepare good-value fertilizers with a compost mixture that comprises $70 \%$ of date palm waste [28]. These by-products are currently used for limited purposes, such as animal (camels, cattle, sheep, and poultry) feed [29,30]. Date seeds are the waste products of the date industry, and approximately 1 million tons of date seeds are produced annually [31]. The seed is a source of edible oil and can be used as a functional food ingredient. Date seeds are also a good source of dietary fiber, phenolic compounds, and essential fatty acids.

\section{Chemical Composition of Date Fruits}

The date palm P. dactylifera is one of the most widely consumed fruits in the world. They are consumed as part of a healthy diet as they are rich in sugar and dietary fibers [2] Date fruits are also a good source of sugar (70-80\% sugar content), which varies according to the species and the stage of maturity of the fruits. The major sugars in most date cultivars are glucose, fructose, and sucrose, which are easily absorbed by the body to provide energy [32]. Several researchers have observed that the total percentage of glucose and fructose is high in the Khalas cultivar $[32,33]$. Sucrose is the dominant sugar in many cultivars such as Sukkary and Nabtat Ali [34]. The total sugar concentration differs between the earlier growth stage and the ripening stage, and sugar concentration usually increases from the Khalal stage to the date stage. Nevertheless, the ecological factors and the type of cultivar also significantly affect the sugar percentage. The average protein content has been recorded to be $1.22-3.30 \%$, fat $0.11-7.33 \%$, ash $1.43-6.20 \%$, and carbohydrates 65.7-88.02\% [35-37]. However, the protein content decreases during the non-enzymatic browning and tannin precipitation stage. Date fruits contain all essential and non-essential amino acids, particularly glutamic acid, lysine, alanine, serine, aspartic acid, proline, and glycine. At the same time, the fatty acids $(0.2-0.5 \%)$ and vitamin contents recorded in date fruits was low [38]. Interestingly, the content of B-complex vitamins was observed to be high in date fruits [39]. Dates contain 1.9-16.95\% dietary fiber, out of which insoluble fiber is recorded as 84-94\%, and soluble fiber content ranges between 6-16\% [36,40,41]. In addition, date fruit contains most of the nutritionally essential minerals, with high levels of potassium, remarkable levels of phosphorus, magnesium, and calcium, as well as low sodium concentrations [42,43] (Table 2). Dietary fiber has important therapeutic effects, and the fiber concentration also depends on the variety and stage of maturity [5,44]. Furthermore, the elemental fluorine and selenium found in date fruit can protect teeth and stimulate immune function in humans. In addition, dates contain $1-2 \%$ phenolic antioxidants, tannin-based pigments, and epicatechin oligomers.

Table 2. Nutrient compositions of date fruit and seed (* $\mathrm{g} / 100 \mathrm{~g} ; \# \mathrm{mg} / 100 \mathrm{~g})$.

\begin{tabular}{cccc}
\hline Component & Date Fruit & Date Seed & References \\
\hline Moisture * $_{\text {Protein * }}$ & $9.43-21.53$ & $8.64-12.25$ & {$[36,40,41]$} \\
Fat * $^{*}$ & $1.22-3.30$ & $4.81-5.84$ & {$[36,40,41]$} \\
Ash * & $0.11-7.33$ & $5.71-8.77$ & {$[36,37,41]$} \\
Carbohydrate * & $1.43-6.20$ & $0.82-1.14$ & {$[37,40,41]$} \\
Dietary fiber * & $65.7-88.02$ & $2.43-4.65$ & {$[37,38,42]$} \\
Magnesium \# & $1.9-16.95$ & $67.56-74.20$ & {$[36,37,41]$} \\
Calcium \# & $56-150$ & $51.7-58.4$ & {$[43,45]$} \\
Phosphorus \# & $123-187$ & $28.9-38.8$ & {$[43,45]$} \\
Potassium \# & $12-27$ & $83.6-68.3$ & {$[43,45]$} \\
Sodium \# & $289.6-512$ & $229-293$ & {$[43,45]$} \\
Iron \# & $4.9-8.9$ & $10.25-10.4$ & {$[43,45]$} \\
\hline
\end{tabular}

\section{Chemical Composition of Date Seeds}

The average weight of date seeds is $5.6-14.2 \%$ of the fruit. They are a good source of phytochemicals such as phenols, sterols, carotenoids, anthocyanins, procyanidins, and 
flavonoids [46,47]. They are also rich in dietary fiber $(67.56-74.20 \%)$, with water-insoluble mannan fiber found at a high percentage. The contents of proteins, vitamins, fatty acids, and minerals were reported to be high in the date seed (Table 2). Insoluble dietary fibers (hemicellulose, cellulose, and lignin) are the main components of seed fiber [48]. Date seeds contain many dietary minerals such as potassium, copper, magnesium, calcium, cadmium, chromium, iron, manganese, zinc, nickel, cobalt, calcium, phosphorous, and lead; the potassium levels were reported to be high (229-293 mg/100 g) [38,43,45,49]. The concentration of minerals in dates increases with maturity in some varieties, such as in the Deglat Noor variety. Other studies have found that the mineral concentration decreases when the dates in five other varieties are ripened [46]. The fatty acid content in the seed varies from $53.2-58.8 \%$, which includes eight types of fatty acids $[38,43]$. They are a good source of unsaturated fatty acids, oleic acid (42.3\%), and linoleic acid (13.7\%). In contrast, the saturated fatty acids, viz., palmitic acid $(9.6 \%)$ and lauric acid $(21.8 \%)$, were reported at minimal concentrations [38,50]. In addition, fruit pulp and seeds contain other fatty acids such as myristic, stearic, and linolenic acids. The predominant fatty acid recorded at a high level was oleic acid, and the levels varied among the species [43]. The advantage of the seed oil is that it has a dark yellowish hue compared to the vegetable oils. Furthermore, it has a high oxidation rate and can be stored for a long time. Therefore, it may be used in cosmetics as a preservative. Oleic acid is used in the cosmetic industry to improve skin permeability through topical applications [51].

\section{Value-Added Products from Date Fruits and Seeds}

Date industries have been looking towards developing value-added products, as they are highly profitable and may reduce the risk of date deterioration. Boulal et al. (2016) achieved bioethanol production from date palm fruit waste by yeast (Saccharomyces cerevisiae)-mediated fermentation [52,53]. Additionally, other studies have demonstrated that date waste can be used as a substrate to produce citric acid using S. cerevisiae and Aspergillus niger [54]. According to Chauhan et al. (2007), date juice is considered as a suitable medium for lactic acid production by Lactobacillus species (KCP01) [55]. Other studies have reported the production of cellulose and xanthan gum by bacterial fermentation $[56,57]$. The raw materials are cheap, and the fermentation process requires limited treatment in these cases. The agro-waste and fruit waste bioconstituents were degraded by microorganisms or by enzyme processing to augment value-added products [58]. Date seed is considered to be one of the major sources of waste during harvest and processing. However, roasted and powdered date seeds are used by some rural communities as coffee substitutes, and in coffee-like preparations in Arabian markets [59]. In addition, date fruit extract, paste, and fermented products are used for making dietary supplements, juice concentrate, syrup, yogurt, bread, confectionery, and preservatives [60-67] (Table 3). Date fruits are also used in the production of high-quality fruit wine [68]. Date seeds constitute a surplus of date fruit by-products due to processing, and its exploitation in food and feed provides an economic advantage [2]. Moreover, they are rich in fiber and phenolic compounds, and they show high oxidative stability and sensory acceptability [69-72]. In addition, fatty acids and oil are derived from date seeds used in cosmetic industries [73,74]. Different kinds of traditional, natural, and man-made materials have been developed from date palm waste, such as mats, screens, baskets, crates, fans, walking sticks, brooms, fishing floats, and fuel.

Moreover, leaf fiber and sheaths are used to prepare packsaddles, rope, coarse cloth, and large hats [75]. Recently, date pits were utilized in bioremediation processes because of their high lignocellulose levels. Additionally, they can be excellent precursors to activated carbon and can be used for heavy-metal remediation of wastewater [76]. Annually, more than 127,000 metric tons of seed oil are extracted from the date pits. The waste and by-products include pigments, dietary fiber, organic acids, sugars, and antibacterial or antifungal compounds, which have shown health-promoting effects in humans [77,78]. Date fruit waste is also considered to have chemoprotective, antioxidant, anti-inflammatory, 
and anticancer properties [79,80]. Meer et al. (2017) demonstrated that date fruit extract significantly improved skin health [73]. Date seeds contain 6-8\% essential oil suitable for usage in the production of moisturizing soaps/creams, shampoos, and other skincare products [81,82]. Moreover, date seed oil has been used in the production of medicine, food, and even cosmetics [74,83].

Table 3. Value-added food and cosmetic products from date fruits and seeds.

\begin{tabular}{|c|c|c|c|}
\hline Type & Source & Products and Application & References \\
\hline \multirow{9}{*}{ Date fruit } & Fruit fiber & $\begin{array}{l}\text { Muffins-increases total dietary fiber and ash } \\
\text { content, improves antioxidant levels }\end{array}$ & {$[51,61]$} \\
\hline & Syrup and powders & $\begin{array}{l}\text { Dairy desserts-natural thickening agent, improves } \\
\text { apparent viscosity and antioxidant activities }\end{array}$ & {$[62]$} \\
\hline & Syrup $(10 \%)$ & $\begin{array}{l}\text { Yogurt-increases sweetness and antioxidant value, } \\
\text { high mineral and folate concentrations }\end{array}$ & {$[63]$} \\
\hline & Fermented fruit puree & $\begin{array}{l}\text { Functional dietary supplement-increases } \\
\text { concentrations of } \gamma \text {-amino butyric acid, conjugated } \\
\text { fatty acids, and insoluble dietary fibers }\end{array}$ & {$[58]$} \\
\hline & Paste & $\begin{array}{l}\text { Pork liver pâté-lowers lipid oxidation and } \\
\text { enhances sensory acceptability }\end{array}$ & {$[64]$} \\
\hline & Pulp powder & Bread-increases dietary fiber content & {$[65]$} \\
\hline & Discarded fruits & High-fructose syrup & {$[66]$} \\
\hline & Immature fruits & Date juice concentrate & {$[67]$} \\
\hline & Wine & Wine & {$[71]$} \\
\hline \multirow{6}{*}{ Date seed (pit) } & Powder & $\begin{array}{l}\text { Pit bread-contains high amounts of phenolics and } \\
\text { increased antioxidant activities }\end{array}$ & {$[69]$} \\
\hline & Powder (defatted) & Bread-increases dietary fiber content & {$[70,71]$} \\
\hline & Extract & $\begin{array}{l}\text { Mayonnaise-ensures high oxidative stability and } \\
\text { sensory acceptability }\end{array}$ & {$[72]$} \\
\hline & Extract & $\begin{array}{l}\text { Oxidative stability of ground beef-increases total } \\
\text { polyphenol content and antioxidant activity and } \\
\text { lowers TBARS value }\end{array}$ & {$[73]$} \\
\hline & Powder & Used as coffee substitute & {$[59]$} \\
\hline & Oil & $\begin{array}{l}\text { Used in ooking, pharmaceutical, and cosmetic } \\
\text { applications }\end{array}$ & {$[51]$} \\
\hline Date fruit and seed & Fatty acid and oil & Used in soap and cosmetic products & {$[74]$} \\
\hline
\end{tabular}

\section{Bioactive Compounds from Date Fruits and Seed}

The date fruit and its seeds are highly nutritional and have medicinal properties owing to their bioactive compounds. However, the potential use of date fruits and seeds in the development of pharmaceutical drugs and cosmetic products has not been fully explored. Date fruits and seeds are rich in non-nutritional compounds such as phytochemicals, such as phenolics, anthocyanins, carotenoids, tocopherols, tocotrienols, phytosterols, and dietary fiber [84-87]. The presence of non-starch polysaccharides, $\alpha$-tocopherols, $\beta$-carotene, ascorbic acid, and selenium-like nutritive bioconstituents has also been reported [84,85]. Fruits are a good source of phenolic compounds, which are biologically active substances containing a benzene hydroxyl ring with a carboxyl group [21]. The fruits contain simple phenolic molecules such as phenolic acids, polyphenols such as flavonoids, and high molecular weight compact polymers (Figure 2). According to Vinson et al. (2005), dried fruits contain extremely high levels of phenolics and, notably, fiber [86]. However, phenolic compounds are essential nutrients of the human diet and show high antioxidant activities [87]. El-Mergawi et al. (2019) demonstrated that the phenolic content and an- 
tioxidant activity in the fruits of 17 Saudi Arabian date cultivars were variable [88]. Date seed oil contained a significant phenolic compound and showed diverse pharmacological effects, such as antimutagenic, anticarcinogenic, and anti-inflammatory activities [89,90]. Several phenolic and flavonoid compounds were found in date fruits [91-100]. Phenolic compounds act as natural antioxidants. They can penetrate the epidermis and dermis and protect the skin from the damaging action of ultraviolet (UV) oxidation and premature skin aging [101,102]. Al-Juhaimi et al. (2018) found gallic acid, syringic acid, and caffeic acid to be the major phenolic acids present in date seeds that could act as pharmaceutical agents [82]. In addition, date seed oil is used in cosmetic formulations such as body creams, shaving soap, and shampoos, as well as in pharmaceutical products [81,103]. Al-Farsi and Lee (2008) showed that date fruits are rich in selenium and contain coenzymes that reduce oxidative stress and infection [5]. In addition, date fruits contain different kinds of flavonoid glycosides such as luteolin, quercetin, and apigenin, which have been found to exist in methylated and sulfated forms. Anthocyanins have been found in fresh fruit, while carotenoids have been found to decrease fruit ripening [47]. However, the metabolites can vary among the cultivars, and both the ecological factors and the fruit ripening stage can affect their quantity and bioactivity $[90,103]$.

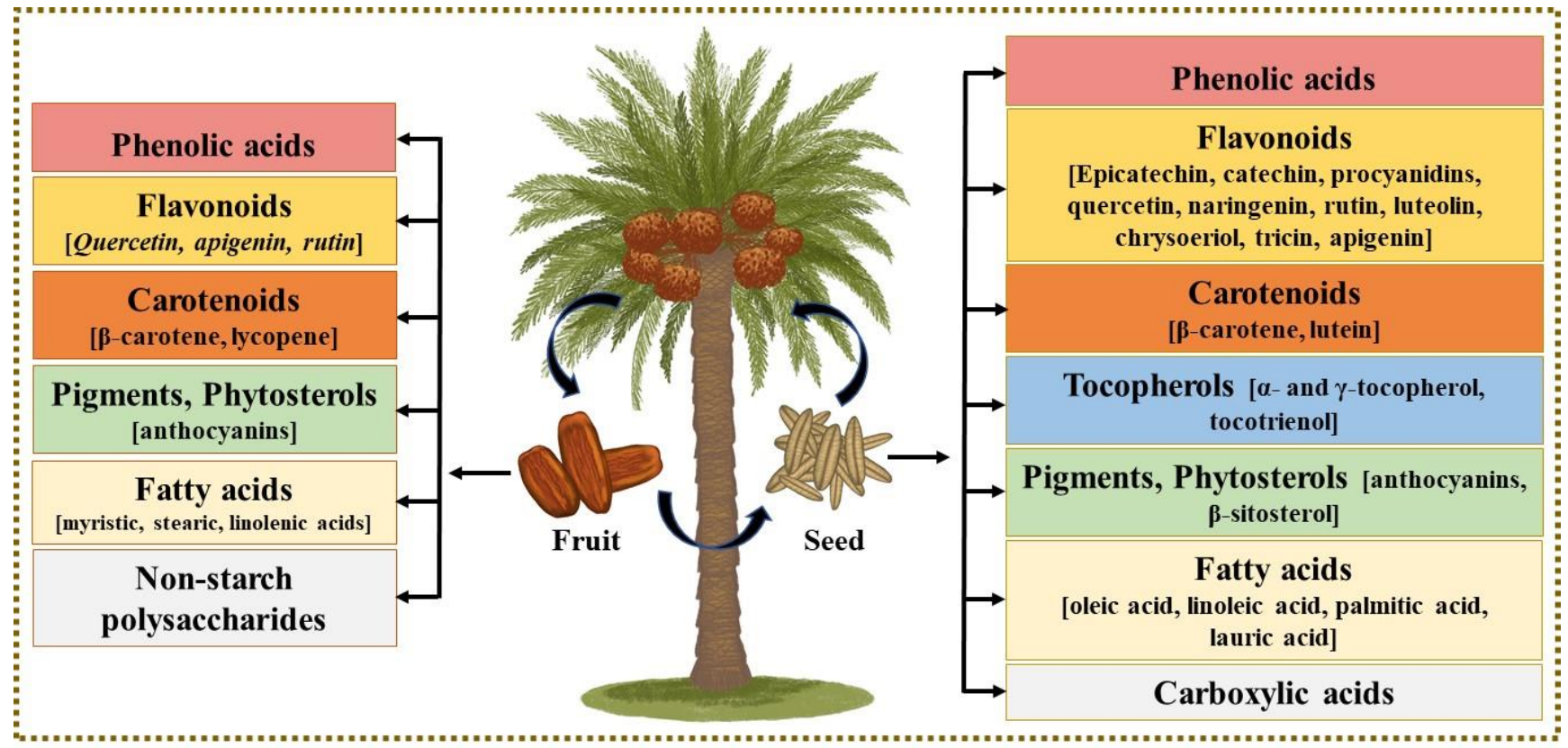

Figure 2. Bioactive constituents from date fruit and seed.

\section{Bioactive Compounds from Date Seeds}

Date seeds are a potentially strong candidate for use as a functional ingredient in human food and animal feed. Moreover, date seed products (seed powder, bread, and extract paste) are safe for human consumption [104]. The seed powder employed as a coffee substitute in coffee drinks may also contain various essential minerals and bioconstituents at optimum levels. The functional ingredient of date seeds has also been used in traditional medicine to relieve toothaches [105]. Phoenix dactylifera has been shown to have immunomodulation activity, and the ability of date seeds to possibly lower the risk of cardiovascular disorders and cancer has been tested to develop a functional food product $[106,107]$. Although date seeds are considered a by-product, they are probably one of the richest edible sources of polyphenolic compounds. Date seed extract and bioactive constituents are considered to be valuable sources for developing drugs and nutraceuticals, because they have been proven to be highly beneficial to humans $[33,108,109]$.

Nevertheless, the organic extraction procedure can also influence the availability and bioactivity of the compounds $[5,110]$. The traditional extraction process using organic 
solvents is harmful and dangerous to humans and the environment. Other studies have reported that supercritical carbon dioxide $\left(\mathrm{SC}-\mathrm{CO}_{2}\right)$ is the optimum method for natural compound extraction out of all the available clean technologies used to extract compounds from date seeds. [37,111]. Several phenolic acids and flavonoids have been reported in date fruits and seeds, which could be considered as an inexpensive source of natural antioxidants. Date seeds are also considered to be a valuable source of other phytochemicals, such as sterols, carotenoids, procyanidins, and anthocyanins. Anthocyanin and flavonoid contents were recorded in high levels in P. dactylifera, which promises to be an exciting source of antioxidant compounds [112]. Additionally, the date seed is a good source of hydroxylated derivatives of benzoic acid (gallic acid, protocatechuic acid, p-hydroxybenzoic acid, and vanillic acid), cinnamic acid derivatives (caffeic acid, coumaric acid, and ferulic acid), quercetin-3-O-glucoside, catechin, procyanidin, tannins, and vitamins such as tocopherol $[22,99]$. However, the aqueous extract of the date seed is composed of components of polyphenols such as isorhamnetin, caffeoyl hexoside, 5-O-caffeoyl shikimic acid isomers, and hydrocaffeic acid $[113,114]$. Furthermore, p-hydroxybenzoic acid, protocatechuic acid, and coumaric acids were the major phenolic acids reported in the date seed $[5,115]$. Nevertheless, other studies have showed that the date seed contains hydroxycinnamic acids, flavanols, epicatechin, and catechin [94] (Figure 2). A list of the bioactive phenolic compounds and their natural sources is provided in Table 4. Commercial production of secondary metabolites from the date seed is still limited, primarily due to the limited availability of information on secondary metabolism and its regulation.

Table 4. List of phenolic acids derived from date fruit and seed and their cosmetic applications.

\begin{tabular}{|c|c|c|}
\hline Components & Source and Bioactivity & References \\
\hline Gallic acid & $\begin{array}{l}\text { Fruit and Seed. Antibacterial and antioxidant. Thermally fluctuating, } \\
\text { Galloyl-RGD (linked with a peptide) used as cosmetic ingredient. }\end{array}$ & {$[81,90,103]$} \\
\hline Vanillic acid & Fruit and seed. Skin lightening and reducing pigmentation. & {$[47,81,90,91]$} \\
\hline Protocatechuic acid & Fruit and Seed. Reduces skin aging process. & {$[81,90,92]$} \\
\hline p-Hydroxybenzoic acid & Fruit and Seed. Increases the shelf life of cosmetics. & {$[83,90,93]$} \\
\hline Syringic acid & $\begin{array}{l}\text { Seed. Fragrance ingredient and surfactant-emulsifying, } \\
\text { surfactant-cleansing tool, skin penetration enhancer. }\end{array}$ & {$[82,94]$} \\
\hline Pelargonic acid & $\begin{array}{l}\text { Fruit and Seed. Thermally fluctuating, Galloyl-RGD used as cosmetic } \\
\text { ingredient. }\end{array}$ & {$[81,90]$} \\
\hline Syringic acid & $\begin{array}{l}\text { Fruit and Seed. Anti-aging, antioxidant, and works as natural } \\
\text { phytochemical in cosmetic products. }\end{array}$ & {$[90,94]$} \\
\hline Cinnamic acid & Fruit and Seed. UV stabilizer, antioxidant, and antimicrobial agent. & {$[83,90,95]$} \\
\hline Caffeic Acid & Fruit and Seed. Antioxidant. & {$[90,96]$} \\
\hline Ferulic acid & $\begin{array}{l}\text { Fruit and Seed. Antioxidant, decreases melanogenesis, improves } \\
\text { angiogenesis and stimulates wound healing, delays photoaging and } \\
\text { promotes skin tone. }\end{array}$ & {$[90,97]$} \\
\hline Catechin & Fruit and Seed. Improves collagen arrangement, binding agent. & {$[81,98,99,101]$} \\
\hline
\end{tabular}

\section{Date Seed Oil and Its Commercial Application}

Date seeds are potentially suitable for daily intake. They contain $4-14 \%$ oil, most of which are saturated (lauric, myristic, and palmitic acids) and unsaturated fatty acids (palmitoleic, oleic, linoleic, and linolenic acids) [93]. However, oleic acid occupies the most significant proportion of oils extracted from dates and seeds. Chemically, oleic acid is also known as omega-9 monounsaturated fatty acid and is abbreviated as C18:1, the most common fatty acid in plants [116]. Date seed oil is considered to be an excellent source of oleic acid compared to bran oil [117]. Moreover, date seed oil exists in liquid form at room temperature and has a bright yellow color with a pleasant odor. Seed oil is an edible oil, 
and, in recent years, it has been viewed as commercially important, owing to its versatile biological constituents and physicochemical properties. Additionally, oil is one of the most important components of date seed and is primarily used in cosmetics. However, date seed contains several medicinal compounds, such as corticosteroids, which can treat kidney and bladder disorders, inflammation, and infectious diseases. Several studies have reported that the date seed shows anti-inflammatory activity $[112,115,118]$.

Moreover, date seed oil contains all phytochemicals, which could be used for many applications such as food product formulations, pharmaceuticals, and cosmetics. Many studies have reported that date seed oil shows antiproliferative activity and significantly reduces oxidative stress $[33,119]$. Date seed oil has also been used in cosmetic ingredients, specifically in the formulation of photoprotective cream [96]. Moreover, date seed oil reduces cellular and oxidative rancidity, and protects the skin from UV irritation. Ines et al. (2010) showed that date seed oil at concentrations higher than $30 \mu \mathrm{g} / \mathrm{mL}$ did not show any toxicity to human skin [120]. Lecheb and Benamara formulated a cosmetic cream from the aqueous extract of $P$. dactylifera fruit seed oil, which showed appreciable fluidity, viscosity, and rheological behavior compared to other cosmetics products [121]. Many other experiments concerning the commercial application and the physicochemical and biochemical properties of date seed oil have also been performed [12,17,24,73] (Figure 2).

\section{Cosmetic Applications of Date Fruits and Seeds}

Date fruits and seeds are considered to have significant nutritive and pharmacological properties. Moreover, they can be used in various cosmetic and beauty products. A lot of cosmetic products contain high amounts of chemical compounds, which are mostly derived synthetics such as hydroquinone [122]. Hammani et al. (2019) reported that activated carbon derived from date stones worked as a catalyst in the reactivity of hydroquinone [123]. In addition, date stones are used in the production of cosmetics. Thus, nanotechnologybased cosmetic products have been attracting consumers; this approach may be used in the design of a new range of cosmetics [124]. The development of nano-based cosmetic delivery vehicles, activated carbon, single-walled nanotubes, and nano-sized vitamin $\mathrm{E}$ has been successfully employed in cosmetics [125]. Natural products have recently been used in cosmetics to treat different skin diseases and protect against UV radiation (Figure 3). UV radiation can cause sunburn, wrinkles, premature aging, and cancer; hence, there is a requirement for a permanent solution for protection from UV radiation and the prevention of its side effects. 


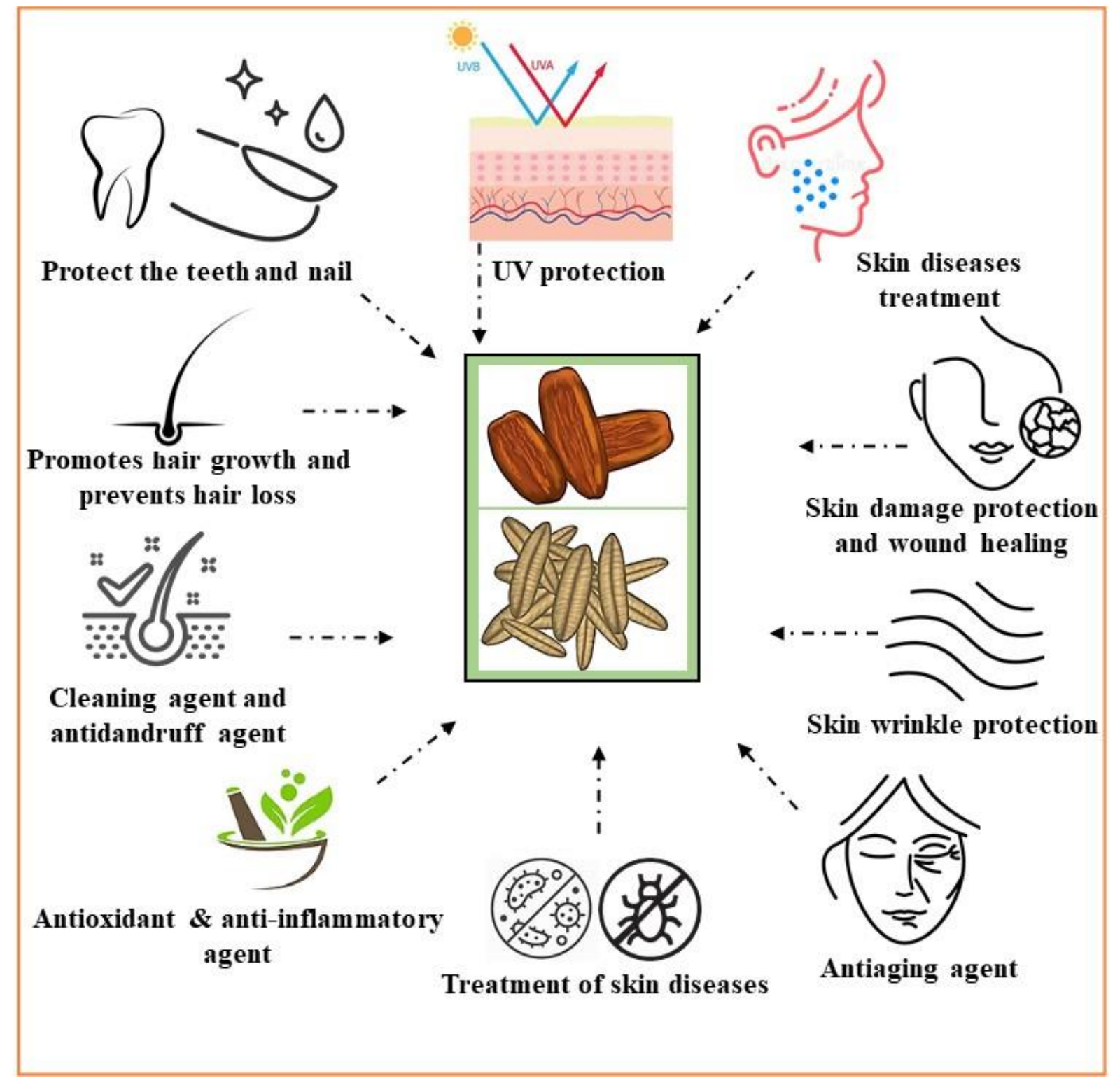

Figure 3. Illustration of the cosmetic applications of date fruits and seeds.

\subsection{Skin Cosmetics}

Date fruits and seeds have great potential for protecting the human skin due to the versatile antioxidant activities and anti-inflammatory properties that they possess. Date fruit and seed waste contain bioactive constituents such as flavonoids, phenolics, and phenolic acids, which play a major role in preventing the generation of free radical species that are the main causative agents of skin damage. Although isolated date seed oil has great potential for protecting the skin, date fruit pulp has shown better potential because of its complex composition. Various physical and psychological stressors, poor nutrition, and UV rays affect the human epidermis; however, natural antioxidants can protect the structural proteins of the skin and reduce skin deterioration [126]. Cosmetic products from natural sources have been found to contain many phytoconstituents, and their demand has increased rapidly in recent years [127]. Consumers' expectations, modern cultural practices, and awareness are geared towards new formulations and safe products [128]. Middle Eastern countries have extensively studied beauty products; however, there is yet a lack of new scientific formulations of cosmetics [129]. Nevertheless, date seed oil has been shown to have a positive effect on human skin and hair, and a few products (body creams, 
soaps, hair products, and sunscreens) have been commercialized. The seed oil has high oxidative stability, an extended storage capacity, and can protect the skin from UV radiation and repair it $[38,130]$. Moreover, date seed oil has shown antiwrinkle properties owing to the presence of phytohormones that can reduce wrinkles and improve skin elasticity [131]. Furthermore, the ascorbic acid and vitamin $\mathrm{E}$ in the date extract improve the moisture level of the skin by stimulating dermal fibroblasts and increasing collagen levels; they also significantly correlate with anti-aging [132]. A commitment to sustainability has generated interest in plant extract research for applications in environmental development and the creation of high-quality cosmetics. Therefore, the use of phenolic extracts has become a vital alternative to traditional applications. It is important to study and evaluate the risks of raw materials and the final products to confirm the absence of toxicity in these extracts. Ahmed et al. (2015) experimentally demonstrated that the administration of seed extract was safe, and that the seeds can serve as natural antioxidants and increase the consumers' quality of life [133]. Ines et al. (2010) reported that date seed oil extract is efficient for the prevention of oxidative damage caused by $\mathrm{H}_{2} \mathrm{O}_{2}$ [111]. The same study also showed that seed oil might serve as a natural antioxidant, owing to the phenols and tocopherols that it contains. Several studies have shown that phenolic compounds contribute to fruit preservation by protecting against photo-oxidation and providing resistance against microbial and parasitic infections [132,134] (Figure 3). The presence of a phenol core acts as a valuable sensor for reactive species and reduces lipid peroxidation. Interestingly, phenolic derivatives are vital in the cosmetic industry for developing ecofriendly products, especially therapeutic products rich in natural raw materials, and in the prevention of premature skin aging [126]. The phenolic content and antioxidant capacity of dates have been studied extensively in Middle Eastern countries; however, there has been little work carried out on cosmetic formulations to realize the potential benefits of natural ingredients derived from dates in cosmetic creams [135].

\subsection{Hair Cosmetics}

Hair and nails are sense organs; they can protect sensitive areas from pollution and help to regulate body temperature. Hair loss can occur as a result of lifestyle changes and a general increase in stress and anxiety. These natural stressors may also affect hair growth and damage the hair color in humans. While nutrient-rich foods may prevent oxidative damage caused by external stress and pollution, plant extracts have been used in hair care to promote hair growth and conditioning, act as cleansing and anti-dandruff agents, and prevent hair loss [136]. The bioactive constituents, such as flavonoids and phenolics, can prevent hair loss and promote hair growth. Flavonoids may increase hair length and follicle size and prolong the stage of development [137]. The compounds of low molecular weight can penetrate the hair and improve the mechanical properties of the cortex, while high molecular weight compounds can protect the hair and prevent degradation. Majeed et al. (2020) reported that coconut water increased hair density and growth in male and female volunteers, and reduced itching sensitivity [138]. Coconut water, which contains flavonoid compounds, may protect the hair follicles. Plant-based antioxidant agents, such as hydroxycinnamic derivatives, are used in cosmetic products to protect the skin and improve hair health. Many plant extracts have been used in hair care to promote hair growth and conditioning, act as cleansing and anti-dandruff agents, and prevent hair loss [136]. Additionally, phenolics and procyanidin flavonoid compounds were reported in P. dactylifera date palm seed [47]. Similarly, cinnamic acid derivatives and water- and lipid-soluble vitamins have been reported in different date varieties [139]. Vitamins B and $\mathrm{E}$ are recommended to strengthen hair and nails, and are found in many cosmetics and health products for hair. Vitamin E promotes the growth of scalp skin cells and acts as an ideal hair conditioner. Additionally, Vitamin E protects nails from aging and can be used to maintain the moisture level, giving the nails a distinctively healthy appearance [140]. 


\subsection{Nail Cosmetics}

Date seed and fruit extracts are good sources of vitamins B, C, and E [141]. Vitamin $\mathrm{C}$ protects the hair and nails from free radicals generated from radiation and pollution. Date seed is also used as an ingredient of eye shadows in traditional cosmetics [142]. It also helps to maintain healthy nails by strengthening the skin, connective tissues, and the walls of blood vessels. A recent study shows that the extract from date seed oil is rich in phytosterols, essential fatty acids, and nutrients needed to maintain a healthy scalp, promote normal hair growth, and support the nutritional functions of sebaceous glands and hair follicles [143] (Figure 3). It is important to note that all synthetic skincare products are made with paraben oil, which may cause allergic reactions and rashes on sensitive skin.

\subsection{Other Nutricosmetics}

Date seed oils are considered safer than parabens and act as natural preservatives in cosmetic products [144]. According to a previous study [109], date seed oil has been shown to have antiviral and anti-inflammatory activities; these properties may protect the skin from inflammation and enhance wound healing [145]. Moreover, date syrup waste (DSW) extract has shown antimicrobial and antioxidant activity, and is currently used in soap manufacturing [146]. Similarly, other studies have reported that date extract containing fluorine could reduce tooth decay [50]. Date seeds have been used as animal feed or soil fertilizers, and have recently been used in many bakery products [2,91]. Therefore, the approach described in this review may present an eco-friendly and cost-effective way to develop organic cosmetic products in the future.

\section{Conclusions}

This review provides a relevant literature summary of the nutritional and chemical composition of date fruits and seeds and their use as cosmetic ingredients. Previous research findings on their nutraceutical and pharmaceutical benefits revealed that consumption of date fruits and seeds could help to prevent oxidative stress and enhance the anti-inflammatory activities of the body. The development of value-added products and cosmetics can prevent neurodegenerative, metabolic, or skin disorders. A variety of date cultivars have shown to be effective inhibitors of tyrosinase and $\alpha$-glucosidase. Therefore, it is important to better understand the mechanism of bioactive constituents and purified compounds that may embody these effects. Chemists and biologists have recognized dates and date seed waste as valuable sources for developing drugs and nutraceuticals because they show many benefits to humans. This review highlights the potential use of date fruits and seeds as valuable new value-added products and cosmetic ingredients. Thus, the use of such waste is essential for increasing the income in this sector through date cultivation and in the use of commercial products for the growth of the cosmetic industry.

Author Contributions: K.L.A. was involved in the writing of the original draft, H.-J.S. provided supervision and validation, and J.R. was involved in reviewing and editing. All authors have read and agreed to the published version of the manuscript.

Funding: This research was funded by the Foreign Ministry of Higher Education, Technical and Vocational Training Corporation, Saudi Arabia, grant number "1990/88510 on 7/2019".

Institutional Review Board Statement: Not applicable.

Informed Consent Statement: Not applicable.

Data Availability Statement: Not applicable.

Acknowledgments: The lead author is hereby acknowledged for her research support through the Research Scholarship Programme (No. 1990/88510 on 7/2019) at the Foreign Ministry of Higher Education, Technical and Vocational Training Corporation, Saudi Arabia. The authors thank the Department of Chemical Engineering in the Graduate School of Chosun University, Republic of Korea.

Conflicts of Interest: The authors declare no conflict of interest. 


\section{References}

1. Ahmed, I.A.; Ahmed, A.W.K.; Robinson, R.K. Chemical composition of date varieties as influenced by the stage repining. Food Chem. 1995, 54, 305-309. [CrossRef]

2. Ghnimi, S.; Umer, S. Date fruit (Phoenix dactylifera L.): An underutilized food seeking industrial valorization. NFS J. 2017, 6, 1-10. [CrossRef]

3. Saudigazette.com.sa. 25 February 2021/13, Rajab, 1442. Available online: https://saudigazette.com.sa (accessed on 24 June 2021).

4. Abdullahi, M.H.; Garko, M. Medicinal value of date palm (Phoenix dactylifera L.). In Proceedings of the Agricultural Society of Nigeria Conference, Nsukka, Nigeria, 11-14 March 2012.

5. Al-Farsi, M.A.; Lee, C.Y. Nutritional and Functional Properties of Dates: A Review. Crit. Rev. Food Sci. Nutr. 2008, 48, 877-887. [CrossRef] [PubMed]

6. Tengberg, M. Beginnings and early history of date palm garden cultivation in the Middle East. J. Arid. Environ. 2012, 86, 139-147. [CrossRef]

7. Al-hajjaj, H.S.; Jamal, Y. Ayad Effect of foliar boron applications on yield and quality of Medjool date palm. J. Appl. Hortic. 2018, 20, 181-188. [CrossRef]

8. Chao, C.C.T.; Krueger, R.R. The Date Palm (Phoenix dactylifera L.) Overview of Biology Uses, and Cultivation. J. Am. Soc. Hortic. 2007, 42, 1077-1082. [CrossRef]

9. FAOSTAT 2020. Available online: http://www.fao.org/faostat/en/\#data/QC/visualize (accessed on 22 December 2020).

10. Mia, M.A.; Mosaib, M.G.; Khalil, M.I.; Islam, M.A.; Gan, S.H. Potentials and safety of date palm fruit against diabetes: A Critical Review. Foods 2020, 9, 1557. [CrossRef]

11. Khalid, S.; Khalid, N.; Khan, R.S.; Ahmed, H.; Ahmad, A. A review on chemistry and pharmacology of ajwa date fruit and pit. Trends Food Sci. Tech. 2017, 63, 60-69. [CrossRef]

12. Nasir, M.U.; Hussain, S.; Jabbar, S.; Rahid, F.; Khalid, N.; Mehmood, A. A review on the nutritional content, functional properties and medicinal potential of dates. Sci. Lett. 2014, 3, 17-22.

13. Guo, C.; Yang, J.; Wei, J.; Li, Y.; Xu, J.; Jiang, Y. Antioxidant activities of peel, pulp and seed fractions of common fruits as determined by FRAP assay. Nutr. Res. 2003, 23, 1719-1726. [CrossRef]

14. Saafi, E.B.; El Arem, A.; Issaoui, M.; Hammami, M. Phenolic content and antioxidant activity of four date palm (Phoenix dactylifera L.) fruit varieties grown in Tunisia. Food Sci. Technol. 2009, 56, 2314-2319.

15. Royan, I.; As'ad, S.; Mappaware, N.A.; Hatta, M.; Rabia. Effect of ajwa dates consumption to inhibit the progression of preeclampsia threats on mean arterial pressure and roll-over test. BioMed Res. Int. 2019, 2019, 2917895. [CrossRef] [PubMed]

16. Ubah, S.A.; Agbonu, O.A.; Kwinjoh, C.P.; Abah, K.O.; Chibuogwu, I.C.; Eneojo, A.S.; Abayomi, S.B.; Enem, S.I.; Ajayi, I.E. Effects of date fruit (Phoenix dactylifera) on sperm cell morphology and reproductive hormonal profiles in cypermethrin-induced male infertility. BioRxiv 2020. [CrossRef]

17. Nehdi, I.A.; Sbihi, H.M.; Tan, C.P.; Rashid, U.; Al-Resayes, S.I. Chemical Composition of Date Palm (Phoenix dactylifera L.) Seed oil from six Saudi Arabian cultivars. J. Food Sci. 2018, 83, 624-630. [CrossRef]

18. Vayalil, P.K. Antioxidant and antimutagenic properties of aqueous extract of date fruit (Phoenix dactylifera L. Arecaceae). J. Agric. Food Chem. 2002, 50, 610-617. [CrossRef] [PubMed]

19. Samir, D.; Anfal, D. Control of lead and cadmium in cosmetic product (Kohl) of pits dates by cyclic voltammetry. J. Chem. Pharm. 2017, 9, 319-323.

20. Al-Bulushi, A.; Attard, T.M.; North, M.; Hunt, A.J. Optimisation and economic evaluation of the supercritical carbon dioxide extraction of waxes from waste date palm (Phoenix dactylifera) leaves. J. Clean. Prod. 2018, 186, 988-996. [CrossRef]

21. Baliga, M.S.; Baliga, B.R. A review of the chemistry and pharmacology of the date fruits (Phoenix dactylifera L.). Food Res. Int. 2011, 44, 1812-1822. [CrossRef]

22. Khan, S.A.; Al Kiyumi, A.R.; Al Sheidi, M.S.; Al Khusaibi, T.S.; Al Shehhi, N.M.; Alam, T. In vitro inhibitory effects on aglucosidase and a-amylase level and antioxidant potential of seeds of Phoenix dactylifera L. Asian Pac. J. Trop. Biomed. 2016, 6, 322-329. [CrossRef]

23. Besbes, S.; Drira, L.; Blecker, C.; Deroanne, C.; Attia, H. Adding value to hard date (Phoenix dactylifera L.): Compositional, functional and sensory characteristics of date jam. Food Chem. 2009, 112, 406-411. [CrossRef]

24. Lattieff, F.A. A study of biogas production from date palm fruit wastes. J. Clean. Prod. 2016, 139, 1191-1195. [CrossRef]

25. Galiwango, E.; AL-Marzouqi, A.H.; Abu-Omar, M.M.; Khaleel, A.A.; Abdelrahman, N.S. Estimating combustion kinetics of UAE Date palm tree Biomass using thermogravimetic Analysis. J. Nat. Sci. Res. 2017, 7, 106-120.

26. Makkawi, Y.; El Sayed, Y.; Salih, M.; Nancarrow, P.; Banks, S.; Bridgwater, T. Fast pyrolysis of date palm (Phoenix dactylifera) wast in a bubbling fluidized bed reactor. Renew. Energy 2019, 143, 1-31. [CrossRef]

27. Ikbel, S.; Liu, X. Anaerobic digestion of waste Tunisian date (Phoenix dactylifera L.): Effect of biochemical composition of pulp and seeds from six varieties. Environ. Technol. 2020, 43, 1-13.

28. Chanderasekaran, M.; Bahkali, A.H. Valorization of date palm (Phoenix dactylifera) fruit processing byproducts and wastes using bioprocess technology. Saudi J. Biol. Sci. 2013, 20, 105-120. [CrossRef]

29. Besbes, S.; Cheikh Rouhou, S.; Blecker, C.; Hentati, B.; Deroanne, C.; Attia, H. Voies de valorisation des pulpes de dates. Microbiol. Hyg. Alim. 2006, 18, 3-7. 
30. Al-Farsi, M.; Lee, C.Y. Usage of Date (Phoenix dactylifera L.) Seeds in Human Health and Animal Feed. In Nuts and Seeds in Health and Disease Prevention; Preedy, V.R., Watson, R.R., Patel, V.B., Eds.; Elsevier: Amsterdam, The Netherlands, 2011; Chapter 53, pp. 447-452.

31. Bouallegue, K.; Allaf, T.; Besombes, C.; Younes, R.B.; Allaf, K. Phenomenological modeling and intensification of texturing/grinding-assisted solvent oil extraction; case of date seeds (Phoenix Dactylifera L.). Arab. J. Chem. 2015, 12, 2398-2410. [CrossRef]

32. Zhang, C.R.; Aldosari, S.A.; Vidyasagar, P.; Shukla, P.; Nair, M.G. Determination of the variability of sugars in date fruit varieties. J. Plant. Crops 2015, 43, 53-61.

33. Habib, H.M.; Ibrahim, W.H. Nutritional quality of 18 date fruit varieties. Int. J. Food Sci. Nutr. 2011, 62, 544-551. [CrossRef]

34. Al-Humaid, A.I.; Mousa, H.M.; El-Mergawi, R.A.; Abdel-Salam, A.M. Chemical composition and antioxidant activity of dates and dates-camel-milk mixtures as a protective meal against lipid peroxidation in rats. Am. J. Food Technol. 2010, 5, 22-30. [CrossRef]

35. Chai, M.N.; Isa, M.I.N. The oleic acid composition effect on the carboxymethyl cellulose based biopolymer electrolyte. JCPT 2013, 3, 1-4. [CrossRef]

36. Alghamdi, A.A.; Awadelkarem, A.M.; Sharif Hossain, A.B.M.; Ibrahim, N.A.; Fawzi, M.; Ashraf, S.A. Nutritional assessment of different date fruits (Phoenix dactylifera L.) varieties cultivated in Hail province, Saudi Arabia. Biosci. Biotech. Res. Comm. 2018, 11, 263-269. [CrossRef]

37. Benmeziane-Derradji, F. Nutritional value, phytochemical composition, and biological activities of Middle Eastern and North African date fruit: An overview. Euro Mediterr. J. Environ. Integr. 2019, 4, 39. [CrossRef]

38. Golshan Tafti, A.; Solaimani Dahdivan, N.; Yasini Ardakani, S.A. Physicochemical properties and applications of date seed and its oil. Int. Food Res. J. 2017, 24, 1399-1406.

39. Siddiq, M.; Greibly, I. Overview of Date Fruit Production, Postharvest Handling, Processing, and Nutrition, Dates: Postharvest Science, Processing Technology and Health Benefits; John Wiley \& Sons, Ltd.: Chichester, UK, 2013; Chapter 1, pp. 1-28.

40. Borchani, C.; Besbes, S.; Blecker, C.; Masmoudi, M.; Baati, R.; Attia, H. Chemical properties of 11 date cultivars and their corresponding fiber extracts. Afr. J. Biotechnol. 2010, 9, 4096-4110.

41. Habib, H.M.; Ibrahim, W.H. Nutritional quality evaluation of eighteen date pit varieties. Int. J. Food Sci. Nutr. 2009, 60, 99-111. [CrossRef]

42. Mohamed, R.M.A.; Fageer, A.S.M.; Eltayeb, M.M.; Ahmed, I.A.M. Chemical composition, antioxidant capacity, and mineral extractability of Sudanese date palm (Phoenix dactylifera L.) fruits. Food Sci. Nutr. 2014, 2, 478-489. [CrossRef]

43. Besbes, S.; Blecker, C.; Deroanne, C.; Drira, N.; Attia, H. Date seeds: Chemical composition and characteristic profiles of the lipid fraction. Food Chem. 2004, 84, 577-584. [CrossRef]

44. Juhaimi, F.A.; Ghafoor, K.; Ozcan, M.M. Physical and chemical properties, antioxidant activity, total phenol and mineral profile of seeds of seven different date fruit (Phoenix dactylifera L.) varieties. Int. J. Food Sci. Nutr. 2012, 63, 84-89. [CrossRef]

45. Assirey, E.A. Nutritional composition of fruit of 10 date palm (Phoenix dactylifera L.) cultivars grown in Saudi Arabia. J. Taibah Univ. Sci. 2015, 9, 75-79. [CrossRef]

46. Tang, Z.X.; Shi, L.E.; Aleid, S.M. Date fruit: Chemical composition, nutritional and medicinal values, products. J. Sci. Food Agric. 2013, 93, 2351-2361. [CrossRef]

47. Hong, Y.J.; Tomas-Barberan, F.A.; Kader, A.A.; Mitchell, A.E. The flavonoid glycosides and procyanidin composition of Deglet Noor dates (Phoenix dactylifera). J. Agric. Food Chem. 2006, 54, 2405-2411. [CrossRef] [PubMed]

48. Shafiei, M.; Karimi, K.; Taherzadeh, M.J. Palm date fibers: Analysis and enzymatic hydrolysis. Int. J. Mol. Sci. 2010, 11, 4285-4296. [CrossRef] [PubMed]

49. Ogungbenle, N.H. Chemical and fatty acid compositions of date palm fruit (Phoenix dactylifera L.) flour. Bangladesh J. Sci. Ind. Res. 2011, 46, 255-258. [CrossRef]

50. Al-shahib, W.; Marshall, R.J. The fruit of the date palm: It's possible use as the best food for the future? Int. J. Food Sci. Nutr. 2009, 54, 247-259. [CrossRef]

51. Mrabet, M.; Jiménez-Araujo, A.; Guillén-Bejarano, R.; Rodriguez-Arcos, R.; Sindic, M. Date seeds: A promising source of oil with functional properties. Foods 2020, 9, 787. [CrossRef]

52. Boulal, A.; Kihal, M.; Khelifi, C.; Benali, B. Bioethanol production from date palm fruit waste fermentation using solar energy. Afr. J. Biotechnol. 2016, 15, 1621-1627.

53. Bouaziz, F.; Abdeddayem, A.B.; Koubaa, M.; Barba, F.J.; Jeddou, K.B.; Kacem, I.; Ghorbel, R.E.; Chaaboun, S.E. Bioethanol production from date seed cellulosic fraction using Saccharomyces cerevisiae. Separations 2020, 7, 67. [CrossRef]

54. Acourene, S.; Djafri, K.; Ammouche, A.; Djidda, A.; Tama, M.; Taleb, B. Utilisation of the date wastes as substrate for the production of baker's yeast and citric acid. Biotechnology 2011, 10, 488-497. [CrossRef]

55. Chauhan, K.; Trivedi, U.; Patel, K.C. Statistical screening of medium components by Plackett-Burman design for lactic acid production by Lactobacillus sp. KCP01 using date juice. Bioresour. Technol. 2007, 98, 98-103. [CrossRef] [PubMed]

56. Moosavi-Nasab, M.; Yousefi, A. Biotechnological production of cellulose by Gluconacetobacter xylinus from agricultural waste. Iran. J. Biotechnol. 2011, 9, 94-101.

57. Moosavi-Nasab, M.; Shekaripour, F.; Alipoor, M. Use of date syrup as agricultural waste for xanthan production by Xanthomonas campestris. Iran Agric. Res. 2009, 28, 89-97. 
58. Di Cagno, R.; Filannino, P.; Cavoski, I.; Lanera, A.; Mamdouh, B.M.; Gobbetti, M. Bioprocessing technology to exploit organic palm date (Phoenix dactylifera L. cultivar Siwi) fruit as a functional dietary supplement. J. Funct. Foods. 2017, 31, 9-19. [CrossRef]

59. Rahman, M.S.; Kasapis, S.; Al-Kharusi, N.S.Z.; Al-Marhubia, I.M.; Khanb, A.J. Composition characterisation and thermal transition of date pits powders. J. Food Eng. 2007, 80, 1-10. [CrossRef]

60. Mrabet, A.; Rodríguez-Gutiérrez, G.; Rubio-Senent, F.; Hamza, H.; Rodríguez-Arcos, R.; Guillen-Bejarano, R.; Sindic, M.; JimenezAraujo, A. Enzymatic conversion of date fruit fiber concentrates into a new product enriched in antioxidant soluble fiber. $L W T$ 2017, 75, 727-734. [CrossRef]

61. Ambigaipalan, P.; Shahidi, F. Date seed flour and hydrolysates affect physicochemical properties of muffin. Food Biosci. 2015, 12, 54-60. [CrossRef]

62. Jridi, M.; Souissi, N.; Salem, M.B.; Ayadi, M.A.; Nasri, M.; Azabou, S. Tunisian date (Phoenix dactylifera L.) by-products: Characterization and potential effects on sensory, textural and antioxidant properties of dairy desserts. Food Chem. 2015, 188, 8-15. [CrossRef]

63. Gad, A.S.; Kholif, A.M.; Sayed, A.F. Evaluation of the nutritional value of functional yogurt resulting from combination of date palm syrup and skim milk. Am. J. Food Technol. 2010, 5, 250-259. [CrossRef]

64. Martin-Sanchez, A.M.; Ciro-Gomez, G.; Sayas, E.; Vilella-Espla, J.; Ben-Abda, J.; Perez-Alvarez, J.A. Date palm by-products as a new ingredient for the meat industry: Application to pork liver pate. Meat Sci. 2013, 93, 880-887. [CrossRef]

65. Bchir, B.; Rabetafika, H.N.; Paquot, M.; Blecker, C. Effect of pear, apple and date fibres from cooked fruit by-products on dough performance and bread quality. Food Bioprocess Technol. 2014, 7, 1114-1127. [CrossRef]

66. Smaali, I.; Jazzar, S.; Soussi, A.; Muzard, M.; Aubry, N.; Marzouki, M.N. Enzymatic synthesis of fructooligosaccharides from date by-products using an immobilized crude enzyme preparation of $\beta$-D-fructofuranosidase from Aspergillus awamori NBRC 4033. Biotechnol. Bioprocess Eng. 2012, 17, 385-392. [CrossRef]

67. Kulkarni, S.G.; Vijayanand, P.; Shubha, L. Effect of processing of dates into date juice concentrate and appraisal of its quality characteristics. J. Food Sci. Technol. 2010, 47, 157-161. [CrossRef] [PubMed]

68. Awe, S.; Nnadoze, S.N. Production and microbiological assesment of date palm (Phoenix dactylifera L.) fruit wine. Microbiol. Res. J. Int. 2015, 8, 480-488. [CrossRef]

69. Platat, C.; Habib, H.M.; Hashim, I.B.; Kamal, H.; AlMaqbali, F.; Souka, U.; Ibrahim, W.H. Production of functional pita bread using date seed powder. J. Food Sci. Technol. 2015, 52, 6375-6384. [CrossRef] [PubMed]

70. Shokrollahi, F.; Taghizadeh, M. Date seed as a new source of dietary fiber: Physicochemical and baking properties. Int. Food Res. J. 2016, 23, 2419-2425.

71. Bouaziz, M.A.; Amara, W.B.; Attia, H.; Blecker, C.; Besbes, S. Effect of the addition of defatted date seeds on wheat dough performance and bread quality. J. Texture Stud. 2010, 41, 511-531. [CrossRef]

72. Amany, M.B.; Shaker, M.A.; Abeer, A.K. Antioxidant activities of date pits in a model meat system. Int. Food Res. J. 2012, 19, 223-227.

73. Meer, S.; Akhtar, N.; Mahmood, T.; Igielska-Kalwat, J. Efficacy of Phoenix dactylifera L. (Date Palm) creams on healthy skin. Cosmetics 2017, 4, 13. [CrossRef]

74. Akbari, M.; Razavizadeh, R.; Mohebbi, G.H.; Barmak, A. Oil characteristics and fatty acid profile of seeds from three varieties of date palm (Phoenix dactylifera) cultivars in Bushehr-Iran. Afr. J. Biotechnol. 2012, 11, 12088-12093. [CrossRef]

75. Othmani, A.; Monia, J.; Karim, K.; Sellemi, A.; Artes, F.; Jameel, M.A.-K. Preharvest fruit drop of date palm (Phoenix dactylifera L.) Cv. Deglet Nour at Kimri Stage: Development, physico-chemical characterization, and functional properties. Int. J. Fruit Sci. 2020, 20, 414-432. [CrossRef]

76. Sivarajasekar, N.; Prakashmaran, J.; Naushad, M.; ALFarhan, B.Z.; Poornima, S.; Sivapriya, S.; Gayathri, V.; Pradeepika, T.; Raghu, V.; Sivamani, S.; et al. Recent Updates on Heavy Metal Remediation Using Date Stones (Phoenix dactylifera L.) -Date Fruit Processing Industry Waste. In Sustainable Agriculture Reviews 34; Sustainable Agriculture Reviews; Naushad, M., Lichtfouse, E., Eds.; Springer: Cham, Switzerland, 2019; Volume 34, pp. 193-206.

77. Fernandez-Lopez, J.; Sendra, E.; Sayas-Barbera, E.; Navarro, C.; Perez-Alvarez, J.A. Physico-chemical and microbiological profiles of "salchichón" (Spanish dry-fermented sausage) enriched with orange fiber. Meat Sci. 2008, 80, 410-417. [CrossRef]

78. Sanchez-Zapata, E.; Fernández-Lopez, J.; Penaranda, M.; Fuentes-Zaragoza, E.; Sendra, E.; Sayas, E.; Perez-Alvarez, J.A. Technological properties of date paste obtained from date by-products and its effect on the quality of a cooked meat product. Food Res. Int. 2011, 44, 2401-2407. [CrossRef]

79. Chakroun, M.; Khemakhem, B.; Mabrouk, H.B.; El Abed, H.; Makni, M.; Bouaziz, M.; Drira, N.; Marrakchi, N.; Mejdoub, H. Evaluation of anti-diabetic and anti-tumoral activities of bioactive compounds from Phoenix dactylifera L's leaf: In vitro and in vivo approach. Biomed. Pharmacother. 2016, 84, 415-422. [CrossRef]

80. Zhang, C.R.; Aldosari, S.A.; Vidyasagar, P.S.P.V.; Shukla, P.; Nair, M.G. Health-benefits of date fruits produced in Saudi Arabia based on in vitro antioxidant, anti-inflammatory and human tumor cell proliferation inhibitory assays. J. Saudi Soc. Agric. Sci. 2017, 16, 287-293. [CrossRef]

81. El Hadrami, A.; Al-Khayri, J.M. Socioeconomic and traditional importance of date palm. Emir. J. Food Agric. 2012, 24, 371-385.

82. Al Juhaimi, F.; Ozcan, M.M.; Adiamo, O.Q.; Alsawmahi, O.N.; Ghafoor, K.; Babiker, E.E. Effect of date varieties on physicochemical properties, fatty acid composition, tocopherol contents, and phenolic compounds of some date seed and oils. J. Food Process Preserv. 2018, 42, e13584. [CrossRef] 
83. Konkol, K.L.; Rasmussen, S.C. An Ancient Cleanser: Soap Productionand Use in Antiquity. In Chemical Technology in Antiquity; Rasmussen, S.C., Ed.; American Chemical Society: Washington, DC, USA, 2015; pp. 245-266.

84. Al-Farsi, M.; Lee, C.Y. Optimization of phenolics and dietary fibre extraction from date seeds. Food Chem. 2008, 108, 977-985. [CrossRef] [PubMed]

85. Shahidi, F.; Naczk, M. Nutritional and Pharmacological Effects of Food Phenolics. In Phenolics in Food and Nutraceuticals; CRC Press LLC: New York, NY, USA, 2004; pp. 331-402.

86. Vinson, J.A.; Zubik, L.; Bose, P.; Samman, N.; Proch, J. Dried fruits: Excellent in vitro and in vivo antioxidants. J. Am. Coll. Nutr. 2005, 24, 44-50. [CrossRef] [PubMed]

87. Cheynier, V. Phenolic compounds: From plants to foods. Phytochem. Rev. 2012, 11, 153-177. [CrossRef]

88. El-Mergawi, A.; AlGeffari, M.A.; Al-Humaid, A. Sugar Types, Phenolic Contents, and Antioxidant Activities for 17 Saudi Arabian Date Cultivars and Their Relations with Glycemic Indices. Int. J. Fruit Sci. 2019, 19, 315-325. [CrossRef]

89. Surh, Y.J. Anti-tumor promoting potential of selected spices ingredients with antioxidative and anti-inflammatory activities. Food Chem. Toxicol. 2002, 40, 1091-1097. [CrossRef]

90. Wilcox, J.K.; Ash, S.L.; Catignani, G.L. Antioxidants and prevention of chronic disease. Crit. Rev. Food Sci. Nutr. 2004, 44, 275-295. [CrossRef]

91. Mansour, A.; Kokkalou, E.; Kefalas, P.; Embarek, G. Phenolic profile and antioxidant activity of the Algerian ripe date palm fruit (Phoenix dactylifera). Food Chem. 2005, 89, 411-420. [CrossRef]

92. Chou, T.H.; Ding, H.Y.; Hung, W.J.; Liang, C.H. Antioxidative characteristics and inhibition of a-melanocyte-stimulating hormone-stimulated melanogenesis of vanillin and vanillic acid from Origanum. Exp. Dermatol. 2010, 19, 742-750. [CrossRef] [PubMed]

93. Shin, S.G.; Cho, S.H.; Park, D.; Jung, E. Anti-Skin aging properties of protocatechuic acid in vitro and in vivo. J. Cosmet. Dermatol. 2020, 19, 977-984. [CrossRef] [PubMed]

94. Kashani, F.Z.; Ghoreishi, S.M.; Khoobi, A. Experimental and statistical analysis on a nanostructured sensor for determination of p-hydroxybenzoic acid in cosmetics. Mater. Sci. Eng. C Mater. Biol. Appl. 2019, 94, 45-55. [CrossRef]

95. Ryu, J.Y.; Na, E.J. MMP expression alteration and MMP-1 production control by syringic acid via AP-1 mechanism. Biomed. Dermatol. 2018, 15, 1-10. [CrossRef]

96. Gunia-Krzyżak, A.; Słoczyńska, K.; Popiół, J.; Koczurkiewicz, P.; Marona, H.; Pękala, E. Cinnamic acid derivatives in cosmetics: Current use and future prospects. Int. J. Cosmet. Sci. 2018, 40, 356-366. [CrossRef] [PubMed]

97. Magnani, C.; Correa, M.A.; Salgado, H.; Isaac, V. Caffeic acid: A review of its potential use in medications and cosmetics. Anal. Methods 2014, 6, 3203-3210. [CrossRef]

98. Zdunska, K.; Dana, A.; Kolodziejczak, A.; Rotsztejn, H. Antioxidant properties of ferulic acid and its possible application. Skin Pharmacol. Physiol. 2018, 31, 332-336. [CrossRef] [PubMed]

99. Madhan, B.; Subramanian, V.; Rao, J.R.; Nair, B.U.; Ramasami, T. Stabilization of collagen using plant polyphenol: Role of catechin. Int. J. Biol. Macromol. 2005, 37, 47-53. [CrossRef]

100. Kwon, O.S.; Han, J.H.; Yoo, H.G.; Chung, J.H.; Cho, K.H.; Eun, H.C.; Kim, K.H. Human hair growth enhancement in vitro by green tea epigallocatechin-3-gallate (EGCG). Phytomedicine 2007, 14, 551-555. [CrossRef] [PubMed]

101. Zilius, M.; Ramanauskienè, K.; Briedis, V. Release of propolis phenolic acids from semisolid formulations and their penetration into the human skin in vitro. Evid. Based Complement. Alternat. Med. 2013, 2013, 958717. [CrossRef] [PubMed]

102. Saleh, A.S.; Tawfik, M.S.; Abu-Tarboush, H.M. Phenolic contents and antioxidant activity of various date palm (Phoenix dactylifera L.) fruits from Saudi Arabia. Food Sci. Nutr. 2011, 2, 1134-1141.

103. Khan, B.A.; Mahmood, T.; Menaa, F.; Shahzad, Y.; Yousaf, A.M.; Hussain, T.; Ray, S.D. New perspectives on the efficacy of gallic acid in cosmetics \& nanocosmeceuticals. Curr. Pharm. Des. 2018, 24, 5181-5187.

104. Platat, C.; Hillary, S.; Tomas-Barberan, F.A.; Martinez-Blazquez, J.A.; Al-Meqbali, F.; Souka, U.; Al-Hammadi, S.; Ibrahim, W. Urine metabolites and antioxidant effect after oral intake of date (Phoenix dactylifera L.) seeds-based products (powder, bread and extract) by human. Nutrients 2019, 11, 2489. [CrossRef]

105. Morton, J.F. Fruits of Warm Climates; Distributed by Creative Resources Systems; J.F. Morton: Miami, FL, USA; Winterville, NC, USA, 1987; pp. 5-11.

106. Adeosun, A.M.; Oni, S.O.; Ighodaro, O.M.; Durosinlorun, O.H.; Oyedele, O.M. Phytochemical, minerals and free radical scavenging profiles of Phoenix dactilyfera L. seed extract. J. Taibah Univ. Med. Sci. 2016, 11, 1-6. [CrossRef]

107. Habib, H.M.; Platat, C.; Meudec, E.; Cheynier, V.; Ibrahim, W.H. Polyphenolic compounds in date fruit seed (Phoenix dactylifera): Characterisation and quantification by using UPLC-DAD-ESI-MS. J. Sci. Food Agric. 2014, 94, 1084-1089. [CrossRef] [PubMed]

108. Hamada, J.S.; Hashim, I.B.; Sharif, F.A. Preliminary analysis and potential uses of date pits in foods. Food Chem. 2002, 76, 135-137. [CrossRef]

109. Al-Meqbaali, F.; Habib, H.; Othman, A.; Al-Marzooqi, S.; AlBawardi, A.; Pathan, J.Y.; Hilary, S.; Souka, U.; Al-Hammadi, S.; Ibrahim, W.; et al. The antioxidant activity of date seed: Preliminary results of a preclinical in vivo, study. Emir. J. Food Agric. 2017, 29, 822-832. [CrossRef]

110. Kchaou, W.; Abbes, F.; Blecker, C.; Attia, H. Effects of extraction solvents on phenolic contents and antioxidant activities of Tunisian date varieties (Phoenix dactylifera L.). Ind. Crop Prod. 2013, 45, 262-269. [CrossRef] 
111. Aris, N.A.B. Extraction of Phoenix Dactylifera (Mariami) Seed oil Using Supercritical Carbon Dioxide. Master's Thesis, Universiti Teknologi Mara, Shah Alam, Malaysia, 2014.

112. Djaoudene, O.; Lopez, V.; Casedas, G.; Les, F.; Schisano, C.; Bachir Bey, M.; Tenore, G.C. Phoenix dactylifera L. seeds: A byproduct as a source of bioactive compounds with antioxidant and enzyme inhibitory properties. Food Funct. 2019, 10, $4953-4965$. [CrossRef]

113. Thouri, A.; Chahdoura, H.; El Arem, A.; Hichri, A.O.; Hassin, R.B.; Achour, L. Effect of solvents extraction on phytochemical components and biological activities of Tunisian date seeds (var. Korkobbi and Arechti). BMC Complement. Altern. Med. 2017, 17, 248. [CrossRef] [PubMed]

114. Hilary, S.; Tomas-Barberan, F.A.; Martinez-Blazquez, J.A.; Kizhakkayil, J.; Souka, U.; Al-Hammadi, S.; Habib, H.; Ibrahim, W.; Platat, C. Polyphenol characterisation of Phoenix dactylifera L. (date) seeds using HPLC-mass spectrometry and its bioaccessibility using simulated in-vitro digestion/Caco-2 culture model. Food Chem. 2020, 311, 125969. [CrossRef] [PubMed]

115. Maqsood, S.; Adiamo, O.; Ahmad, M.; Mudgil, P. Bioactive compounds from date fruit and seed as potential nutraceutical and functional food ingredients. Food Chem. 2020, 308, 125522. [CrossRef]

116. Kostik, V.; Memeti, S.; Bauer, B. Fatty acid composition of edible oils and fats. J. Hyg. Eng. 2013, 4, 112-116.

117. Abdul Afiq, M.J.; Abdul Rahman, R. Date seed and date seed oil. Int. Food Res. J. 2013, 20, 2036-2040.

118. Rahmani, A.H.; Aly, S.M.; Ali, H.; Babiker, A.Y.; Srikar, S.; Khan, A.A. Therapeutic effects of date fruits (Phoenix dactylifera) in the prevention of diseases via modulation of anti-inflammatory, anti-oxidant and anti-tumour activity. Int. J. Clin. Exp. Med. 2014, 7, 483-491.

119. Dammak, I.; Boudaya, S.; Abdallah, F.B.; Hamida, T.; Attia, H. Date seed oil inhibits hydrogen peroxide-induced oxidative stress in normal human epidermal melanocytes. Connect. Tissue Res. 2009, 50, 330-335. [CrossRef]

120. Ines, D.; Sonia, B.; Fatma, B.A.; Souhail, B.; Hamadi, A.; Hamida, T.; Basma, H. Date seed oil inhibits Hydrogen peroxide-induced oxidative stress in human epidermal keratinocytes. Int. J. Dermatol. 2010, 49, 262-268. [CrossRef] [PubMed]

121. Lecheb, F.; Benamara, S. Feasibility study of a cosmetic cream added with aqueous extract and oil from date (Phoenix dactylifera L.) fruit seed using experimental design. Int. J. Cosmet. Sci. 2015, 66, 359-370.

122. Gunter, S.; SvenGohla, J.S.; Whaltrand, K.; Uwe Schonrock, H.; Schmidt, L.; Annegret, K.; Xenia, P.; Wolfgang, P.; Hellmut, I.; Walter, D. Skin Cosmetics. In Ullmann's Encyclopedia of Industrial Chemistry; Willey VCH: Weinheim, Germany, 2005; pp. 280-285.

123. Hammani, H.; Laghrib, F.E.; Farahi, A.; Lahrich, S. Preparation of activated carbon from date stones as a catalyst to the reactivivty of hydroquinone: Application in skin whitening cosmetics samples. J. Sci. Adv. Mat. Devices 2019, 4, 451-458. [CrossRef]

124. Raj, S.; Jose, S.; Sumod, U.S.; Sabitha, M. Nanotechnology in cosmetics: Opportunities and challenges. J. Pharm. Bioallied. Sci. 2012, 4, 186-193. [CrossRef]

125. Song, C.; Liu, S. A new healthy sunscreen system for human: Solid lipid nanoparticles as carrier for 3,4,5-trimethoxybenzoylchitin and the improvement by adding vitamin E. Int. J. Biol. Macromol. 2005, 36, 116-119. [CrossRef] [PubMed]

126. Cherubim, D.J.; Martins, C.V.; De Farina, L.O.; Lucca, R.A. Polyphenols as natural antioxidants in cosmetics applications. J. Cosmet. Dermatol. 2020, 19, 33-37. [CrossRef] [PubMed]

127. Pouillot, A.; Polla, L.; Tacchini, P.; Neequaye, A.; Polla, A.; Polla, B. Natural Antioxidants and their Effects on the Skin chapter13. In Formulating, Packaging, and Marketing of Natural Cosmetic Products; Dayan, N., Kromidas, L., Eds.; John Wiley \& Sons, Inc.: Hoboken, NJ, USA, 2011; pp. 239-257.

128. Amberg, N.; Fogarassy, C. Green Consumer Behavior in the Cosmetics Market. Resources 2019, 8, 137. [CrossRef]

129. Djouab, A.; Benamara, S.; Gougam, H.; Amellal, H.; Hidous, K. Physical and antioxidant properties of two Algerian date fruit species (Phoenix Dactylifera L. And Phoenix Canariensis, L.). Emir. J. Food. Agric. 2017, 28, 601-608. [CrossRef]

130. Abdalla, R.S.M.; Albasheer, A.A.; ELHussein, A.R.M.; Gadkariem, E.A. Physico-chemical characteristics of date seed oil grown in Sudan. Am. J. Appl. Sci. 2012, 9, 993-999.

131. Younas, A.; Naqvi, S.A.; Khan, M.R.; Shabbir, M.A.; Jatoi, M.A.; Anwar, F.; Inam-Ur-Raheem, M.; Saari, N.; Aadil, R.M. Functional food and nutra-pharmaceutical perspectives of date (Phoenix dactylifera L.) fruit. J. Food Biochem. 2020, 44, e13332. [CrossRef]

132. BouHlali, E.; Ramchoun, M.; Alem, C.; Ghafoor, K.; Ennassir, J.; Zegzouti, Y.F. Phytochemical compositions and antioxidant capacity of three date (Phoenix dactylifera L.) seeds varieties grown in the South East Morocco. J. Saudi Soc. Agric. Sci. 2017, 16, 350-357. [CrossRef]

133. Ahmed, A.F.; Al-Qahtani, J.H.; Al-Yousef, H.M.; Al-Said, M.S.; Ashour, A.E.; Al-Sohaibani, M.; Rafatullah, S. Proanthocyanidinrich date seed extract protects against chemically induced hepatorenal toxicity. J. Med. Food 2015, 18, 280-289. [CrossRef] [PubMed]

134. Moran, A.; Gutierrez, S.; Martinez-Blanco, H.; Ferrero, M.A.; Monteagudo-Mera, A.; Rodriguez-Aparicio, L.B. Non-toxic plant metabolites regulate Staphylococcus viability and biofilm formation: A natural therapeutic strategy useful in the treatment and prevention of skin infections. Biofouling 2014, 30, 1175-1182. [CrossRef]

135. Kazemi, M.; Dadkhah, A. Antioxidant activity of date seed oils of fifteen varieties from Iran. Orient. J. Chem. 2012, 28, 1201-1205. [CrossRef]

136. Patel, S.; Sharma, V.; Chauhan, N.S.; Thakur, M.; Dixit, V.K. Hair Growth: Focus on herbal therapeutic agent. Curr. Drug Discov. Technol. 2015, 12, 21-42. [CrossRef]

137. Adhirajan, N.; Ravi Kumar, T.; Shanmugasundaram, N.; Babu, M. In vivo and in vitro evaluation of hair growth potential of Hibiscus rosa-sinensis Linn. J. Ethnopharmacol. 2003, 88, 235-239. [CrossRef] 
138. Majeed, M.; Majeed, S.; Nagabhushanam, K.; Mundkur, L.; Neupane, P.; Shah, K. Clinical study to evaluate the efficacy and safety of a hair serum product in healthy adult male and female volunteers with hair fall. Clin. Cosmet. Investig. Dermatol. 2020, 13, 691-700. [CrossRef] [PubMed]

139. Messaoudi, R.S.; Abbeddou, S.; Mansouri, A.; Calokerinos, A.C.; Kefalas, P. Phenolic profile and antioxidant activity of date-pits of seven Algerian date palm fruit varieties. Int. J. Food Prop. 2013, 16, 1037-1047. [CrossRef]

140. Dattola, A.; Silvestri, M.; Bennardo, L.; Passante, M.; Scali, E.; Patruno, C.; Nistico, S.P. Role of vitamins in skin health: A Systematic Review. Curr. Nutr. Rep. 2020, 9, 226-235. [CrossRef]

141. Al-Alawi, R.A.; Al-Mashiqri, J.H.; Al-Nadabi, J.S.M.; Al-Shihi, B.I.; Baqi, Y. Date palm tree (Phoenix dactylifera L.): Natural products and therapeutic options. Front. Plant Sci. 2017, 8, 845. [CrossRef]

142. Benchelah, A.C.; Maka, M. Les dattes de la prehistoire a nos jours. Phytotherapie 2006, 1, 43-47. [CrossRef]

143. Walke, D.D.; Daud, F.S. Date palm fruit (Phoenix dactylifera L.) as a cosmetic ingredient. JETIR 2018, 5, 755-762.

144. DiBaise, M.; Tarleton, S.M. Hair, Nails, and Skin: Differentiating cutaneous manifestations of micronutrient deficiency. Nutr. Clin. Pract. 2019, 34, 490-503. [CrossRef]

145. Hasson, S.S.; Al-Shaqsi, M.S.; Albusaidi, J.Z.; Al-Balushi, M.S.; Hakkim, F.L.; Aleemallah, G.M.; Al-Jabri, A.A. Influence of different cultivars of Phoenix dactylifera L-date fruits on blood clotting and wound healing. Asian Pac. J. Trop. Biomed. 2018, 8, 371-376. [CrossRef]

146. Rambabu, K.; Edathil, A.A.; Nirmala, G.S.; Hasan, S.W.; Yousef, A.F.; Show, P.L.; Banat, F. Date-fruit syrup waste extract as a natural additive for soap production with enhanced antioxidant and antibacterial activity. Environ. Technol. Innov. 2020, 20, 101153. [CrossRef] 